Науковий вісник Аьвівського національного університету ветеринарної медицини та біотехнодогій імені С.3. Гжицького

\author{
Scientific Messenger of Lviv National University \\ of Veterinary Medicine and Biotechnologies
}

\title{
The influence of seasonal factors on the content of keratoses, free internal lipids, and physical characteristics of sheep wool
}

\author{
V.M. Tkachuk ${ }^{1}$, P.V. Stapay ${ }^{2}$, N.R. Mot'ko $^{3}$ \\ ${ }^{1}$ Institute of agriculture of Carpathian region of NAAS, Obroshyno, Lviv region, Ukraine \\ ${ }^{2}$ Institute of Animal Biology of NAAS, Lviv, Ukraine \\ ${ }^{3}$ Stepan Gzhytskyi National University of Veterinary Medicine and Biotechnologies Lviv, Ukraine
}

Article info

Received 10.01.2018

Received in revised form 26.02 .2018

Accepted 30.02.2018

Institute of agriculture of Carpathian region of $N A A S$,

Grushevskogo Str., 5, Obroshyno, Lviv region, 81115 , Ukraine.

Tel.: +38-063-457-94-48

E-mail: vitalii-tkachuk@ukr.net

Institute of Animal Biology of NAAS, V. Stus Str., 38 Lviv, 79034, Ukraine.

E-mail:inenbiol@mail.lviv.ua

Stepan Gzhytskyi National University of Veterinary Medicine and Biotechnologies Lviv, Pekarska Str., 50, Lviv, Ukraine. E-mail:admin@lvet.edu.ua
Tkachuk, V.M., Stapay, P.V., \& Mot'ko, N.R. (2018). The influence of seasonal factors on the content of keratoses, free internal lipids, and physical characteristics of sheep wool. Scientific Messenger of Lviv National University of Veterinary Medicine and Biotechnologies. 20(84), 44-48. doi: $10.15421 /$ nvlvet 8408

Wool formation is a complex and multifaceted process, which depend on a lot of factors, namely genet$i c$, alimentary, animal maintenance conditions, including seasonal factors' impact. Seasonal weather changes or so-called photoperiodism, changing the retention and feeding regimes by periods of the year, highly correlate with the physiological state of the organism of the sheep and influence the growth and quality of the wool. Given this the purpose of our work was to investigate the impact of the season on the macrostructure, chemical composition and physical properties of wool. For the research wool of ewe breed precos was used, the samples of which were taken in different seasons, in particular winter, spring, summer and autumn periods of animal maintenance. In the wool there were determined the contents of keratoses and free internal lipids, as well as the strength of the fibers at the break. It was established that wool that grew in the winter and spring period contains the largest amount of protein macro- and microfiber, i.e. alpha keratosis. Instead, with the onset of summer and until autumn the amount of this fraction decreased by an average of $2 \%$. A similar trend was observed on the part of beta keratosis, however, these changes were less significant and did not exceed one percent. It has been established that the content of gamma keratosis, i.e. matrix of fiber, is on the highest level in summer and spring periods, that is, the periods of the best alimentary provision of animals. In the pasture period in the sheep wool there is the biggest amount of free internal lipids (1.1\%). In the autumn period, their number begins to decrease gradually and the lowest one is recorded in the winter-stool period (0.9\%). The most distinct seasonal changes among these lipids are fixed by cholesterol factions. In particular, the largest number of unesterified cholesterol is contained in the wool of winter growth $-67.2 \%$. With the onset of spring the amount of this fraction decreases up to $62.3 \%$ $(P<0.01)$ and the trend continues in the summer $(61.6 \%, P<0.001)$ and autumn $(60.8 \%, P<0.01)$ periods. Regarding unesterified cholesterol, there is a diametrically opposite picture of changes. It was established that the strength of the wool of the summer-autumn growth period is bigger by $12 \%$, in comparison with the wool that grew in the winter-stool period. It is shown that there is a positive correlation between the strength of fibers and the content of ceramides in them, which in the winter period was 0.923, in the spring one was 0.989, for summer it was 0.827, in autumn it was 0.786.

Key words: wool, ewe, season, keratoses, free internal lipids, strength, ceramides, correlation.

\section{Вплив сезонних факторів на вміст кератоз, вільних внутрішніх ліпідів та фізичні показники вовни овець}

\author{
В.М. Ткачук ${ }^{1}$, П.В. Стапай${ }^{2}$ Н.Р. Мотько ${ }^{3}$ \\ ${ }^{1}$ Інститут сільського господарства Карпатського регіону НААН, с. Оброшино, Львівська обл., Украӥна \\ ${ }^{2}$ Інститут біології тварин НААН, м. Львів, Украӥна \\ ${ }^{3}$ Львівський національний університет ветеринарної медицини та біотехнологій імені С.3. Гжицького, \\ м. Львів, Україна
}


Вовноутворення - складний та багатогранний процес, який залежить від багатьох чинників, а саме генетичних, аліментарних, умов утримання тварин, у тому числі і впливу сезонних факторів. Для дослідження використовували вовну вівцематок породи прекос, зразки якої відбирали у різні сезони року, зокрема у зимовий, весняний, літній та осінній періоди утримання тварин. Встановлено, щуо вміст гамма-кератози, тобто матриксу волокна, є найвищим у літній та осінній періоди, тобто періоди найкращого аліментарного забезпечення тварин. У пасовищний період у вовні овець також міститься найвища кількість вільних внутрішніх ліпідів (1,1\%). У осінній період їхня кількість починає поступово зменшуватися, $і$ найменше їх зафіксовано у зимово-стійловий період (0,9\%). Найбільш чіткі сезонні зміни серед ичих ліпідів зафіксовані з боку холестеролових фракцій. Зокрема, найбільиа кількість неетерифікованого холестеролу міститься у вовні зимового росту - 67,2\%. 3 настанням весни кількість иієї фракції зменшується до 62,3\% (P<0,01), і ияя тендениія продовжується у літній $(61,6 \%, P<0,001)$ та осінній (60,8\%, $><0,01)$ періоди. Щодо етерифікованого холестеролу, то тут спостерігається діаметрально протилежна картина змін. Встановлено, ияо міцність вовни літньо-осіннього періоду росту є більшою на 12\% порівняно з вовною, яка виросла у зимово-стійловий період. Показано, щчо між міцністю волокон та вмістом у них церамідів існує позитивний зв'язок, який у зимовий період становив - 0,923, весняний 0,989, літній-0,827, осінній-0,786.

Ключові слова: вовна, вівцеематки, сезон, кератози, вільні внутрішні ліпіди, міцність, цераміди, кореляція.

\section{Ветуп}

Вівці більшою мірою, ніж інші сільськогосподарські тварини, залежні від впливу погоди, оскільки утримуються на пасовищах не менше 6-ти місяців, а у деяких регіонах пасуться протягом року. Отже, дощ, сніг, спека, холод, надмірна сухість і вологість, різкі зміни погоди постійно впливають на організм і можуть призвести до захворювань, а то й загибелі тварин (Stapay et al., 2014).

У цьому плані роль вовнового покриву овець як захисного пристосування організму до впливів погоди має велике значення і в умовах культурного ведення вівчарства. Тому для практики вівчарства важливо знати, як змінюється якість вовни від кліматичних умов та який тип вовнового покриву найкраще захищає тварин від несприятливої погоди, залежно від різних кліматичних зон (Adams et al., 1999).

Сезонні зміни погоди, або так званий фотоперіодизм, переміна режимів утримання і годівлі за періодами року високо корелюють 3 фізіологічним станом організму овець і впливають на ріст та якість вовни. Найбільш інтенсивний ріст вовни спостерігається у період виходу овець на пасовище, влітку та восени; у холодні зимові місяці приріст вовни значно уповільнюється (Myros et al., 2011).

3 огляду на це метою нашої роботи було дослідити вплив сезону на макроструктуру, хімічний склад та фізичні властивості вовни.

\section{Матеріал та методи досліджень}

Об'єктом досліджень служили зразки вовни, які відбиралися у зимовий, весняний, літній та осінній періоди від вівцематок породи прекос, які належали ННВЦ «Комарнівське» Львівського національного університету ветеринарної медицини та біотехнологій ім. С.3. Гжицького.

Зразки вовни промивали в нейтральному миючому розчині, ретельно ополіскували і висушували. Жиропіт видаляли шляхом екстрагування в апараті Сокслетта за допомогою чотирихлористого вуглецю протягом 5 годин, а потім сумішшю спирт-ефіром.

Кількісне співвідношення кератоз у вовні визначали за методом R.S. Asquith (Asquith and Parkinson, 1966). Дослідження вільних внутрішніх ліпідів вовни проводили за описаними нами методами (Tkachuk et al., 2014). Міцність волокон на розрив досліджували на апараті ДШ-3М.

\section{Результати та їх обговорення}

Із даних таблиці 1, у якій проведено результати дослідження макроструктури вовни, тобто так званих кератоз, видно, що у процесі річного росту вовни сезонні фактори істотно не відобразилися на структурній організації волокна, хоча деякі зміни все ж таки спостерігаються. Так, $з$ цифрових даних видно, що вовна, яка виросла у зимово-весняний період, характеризується найбільшою кількістю білка макро- i мікрофібрил, тобто альфа-кератози. Натомість 3 настанням літа і до осені кількість цієї фракції зменшувалася в середньому на 2\%. Подібна тенденція спостерігалася і з боку бета-кератози, однак ці зміни були менш суттєвими і не перевищували одного відсотка (табл. 1).

Водночас діаметрально протилежна картина змін спостерігалася з боку гамма-кератози, тобто матриксу волокна. Так, найменша кількість цієї фракції була зафіксована у вовні зимово-весняного періоду росту, а 3 настанням літа кількість цієї фракції зростала в середньому на $3 \%$.

\section{Таблиця 1}

Сезонна динаміка співвідношення кератоз вовни, \% $(\mathrm{M} \pm \mathrm{m}, \mathrm{n}=3)$

\begin{tabular}{lcccc}
\hline & \multirow{2}{*}{ Кератоза } & \multicolumn{3}{c}{ Сезон } \\
\cline { 2 - 5 } & Зима & Весна & Літо & Осінь \\
\hline Альфа & $59,83 \pm 1,95$ & $59,30 \pm 1,27$ & $57,60 \pm 1,22$ & $57,33 \pm 1,42$ \\
Бета & $11,47 \pm 0,61$ & $11,33 \pm 0,52$ & $10,60 \pm 0,31$ & $10,73 \pm 0,27$ \\
Гамма & $28,70 \pm 2,28$ & $29,37 \pm 0,84$ & $31,80 \pm 1,30$ & $31,93 \pm 1,69$ \\
\hline
\end{tabular}


Встановлені зміни можуть бути пов'язані насамперед 3 аліментарними факторами, зокрема рівнем забезпеченості організму вівцематок Сульфуром, оскільки саме гамма-кератоза містить найбільшу кількість цього надважливого для організму вівці макроелементу.

Водночас сезонні фактори істотно відобразилися на кількості та співвідношенні структурних ліпідів волокон. Нагадаємо, що у структурі волоса міститься незначна кількість (до 3\%) ліпідів, які перебувають у двох формах - вільній та зв'язаній. Ймовірно, що ці ліпіди $є$ головними компонентами плазматичних мембран клітин волоса і визначають його поверхневі властивості (Marti et al., 2007; 2010).

Зокрема показано, що кількість вільних внутрішніх ліпідів у вовні в різні періоди іiі росту є різною. Так, найменша їх кількість містилася у вовні, яка виросла у зимово-стійловий період утримання тварин. 3 настанням весняного періоду кількість загальних ліпідів збільшується і досягає максимуму в літній період. У осінній період їх кількість починає поступово зменшуватися і як було сказано, найменше їх $є$ у зимово-стійловий період (табл. 2).

Зокрема, з цифрових даних таблиці 2 видно, що найбільша кількість ліпідів розділених у системі петролейний ефір-диетиловий ефір (4:1) припадає на холестеролові фракції - фракцію неетерифікованого $(60,78-67,15 \%)$ і етерифікованого холестеролу $(9,01-$ $14,08 \%)$. Ще одна фракція стеринового походження (можливо це ланостерол) займає від 12,55 до 14,67\%.
На неетерифіковані жирні кислоти припадає 10,62$13,59 \%$

Найбільш чіткі сезонні зміни серед цих ліпідів зафіксовані також з боку холестеролових фракцій. Зокрема, найбільша кількість неетерифікованого холестеролу міститься у вовні зимового росту. 3 настанням весни кількість цієї фракції зменшується і ця тенденція продовжується у літній та осінній періоди. Щодо етерифікованого холестеролу, то тут спостерігається діаметрально протилежна картина змін. Найменша кількість цієї фракції є у зимовий період, а починаючи 3 весни ії кількість починає наростати і досягає свого піку у літньо-осінній період. У зимовий період також відмічено найнижчий вміст неідентифікованої нами стеринової фракції.

Динамічність ліпідів, розділених у системі хлороформ-метанол-вода (65: $25: 4)$, виявилася досить високою. Так, кількість основного компонента полярних ліпідів - церамідів, а також гліколіпідів найвищої полярності 3 настанням весни поступово зростає i досягає свого максимуму у літньо-осінній період. 3 огляду на це, нагадаємо, що у структурній будові кератинів специфічна роль церамідів пов'язана з формуванням інтрацелюлярних ламелл (пластин) рогового шару, які є сплющеними везикулами, що виштовхнені з ламеллярних гранул у міжклітинний простір. Ці сплющені везикули з'єднуються у спосіб «ребро до ребра» («край до краю»), утворюючи таким чином спарений бішар (Coderch et al., 2008; Ramirez et al., 2010).

\section{Таблиця 2}

Сезонна динаміка співвідношення вільних внутрішніх ліпідів вовни, \% $(\mathrm{M} \pm \mathrm{m}, \mathrm{n}=3)$

\begin{tabular}{|c|c|c|c|c|}
\hline \multirow{2}{*}{ Ліпіди } & \multicolumn{4}{|c|}{ Сезон } \\
\hline & Зима & Весна & Літо & Осінь \\
\hline Загальна кількість & $0,93 \pm 0,05$ & $1,02 \pm 0,05$ & $1,08 \pm 0,05$ & $1,03 \pm 0,06$ \\
\hline \multicolumn{5}{|c|}{3 них: ліпіди розділені у системі петролейний ефір-диетиловий ефір (4:1) } \\
\hline Неетерифікований холестерол & $67,15 \pm 0,52$ & $62,28 \pm 0,79 * *$ & $61,57 \pm 0,33 * * *$ & $60,78 \pm 1,18^{* *}$ \\
\hline НЕЖК & $11,29 \pm 0,60$ & $13,59 \pm 0,37^{*}$ & $10,62 \pm 0,21$ & $11,97 \pm 1,23$ \\
\hline Стеринова фракція & $12,55 \pm 0,51$ & $14,67 \pm 0,98$ & $14,31 \pm 0,71$ & $13,17 \pm 0,98$ \\
\hline Етерифікований холестерол & $9,01 \pm 0,58$ & $9,46 \pm 1,09$ & $13,49 \pm 0,61 * *$ & $14,08 \pm 0,87 * *$ \\
\hline \multicolumn{5}{|c|}{ ліпіди розділені у системі хлороформ-метанол-вода $(65: 25: 4)$} \\
\hline Гліколіпіди найвищої полярності & $3,08 \pm 0,24$ & $3,63 \pm 0,31$ & $3,67 \pm 0,17$ & $4,76 \pm 0,20 * *$ \\
\hline Холестерол сульфат & $9,88 \pm 0,23$ & $8,00 \pm 0,47^{*}$ & $9,41 \pm 0,29$ & $9,58 \pm 0,37$ \\
\hline Глюкозил цераміди & $14,45 \pm 0,66$ & $14,32 \pm 0,70$ & $13,29 \pm 0,25$ & $14,31 \pm 0,25$ \\
\hline Сульфоліпіди & $26,37 \pm 1,81$ & $24,99 \pm 1,34$ & $21,94 \pm 0,27$ & $21,01 \pm 0,70^{* *}$ \\
\hline Цераміди & $46,22 \pm 1,09$ & $49,07 \pm 1,86$ & $51,69 \pm 0,31 * *$ & $50,34 \pm 1,10$ \\
\hline
\end{tabular}

Примітка: статистично вірогідні різниці: *- $\mathrm{P}<0,05 ; * *-\mathrm{P}<0,01 ; * * *-\mathrm{P}<0,001$

Щодо сульфуровмісних класів полярних ліпідів, а саме сульфоліпідів і холестерол сульфату, то за умов наших дослідів також зафіксовані певні зміни. Так, найбільша кількість сульфоліпідів характерна для вовни зимового росту. 3 настанням весни і впродовж усього літньо-осіннього періоду їхня кількість поступово зменшується, а вміст холестерол сульфату в усі сезони року $є$ майже однаковий, і лише у весняний період спостерігається його зменшення.

Отже, з наведених даних випливає, що вміст окремих класів структурних ліпідів значною мірою залежить від сезонних факторів, серед яких важливу роль відіграє рівень і характер живлення овець. Підтвердженням цього можуть бути дані фізичних показників волокон, зокрема їх міцності.

Так, з даних рисунка видно, що закономірним є вірогідне зростання показників міцності вовни у літній та, особливо, осінній періоди, тобто періоди найкращого аліментарного забезпечення овець. Так, міцність вовни літньо-осіннього періоду росту є більшою на 12 відсотків порівняно з вовною, яка виросла у зимово-стійловий період. 


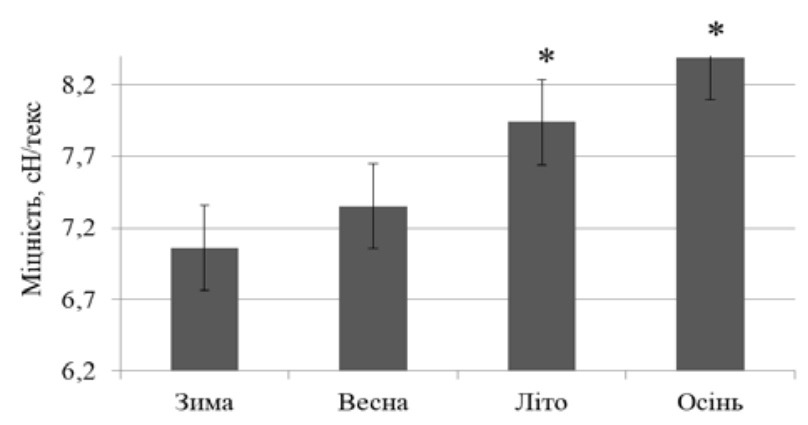

Рис. Сезонна динаміка міцності вовни (*-P $<0,01-$ статистично вірогідні різниці між різними сезонами)
Аналіз отриманих даних також засвідчив (табл. 3), що міцність вовняних волокон залежить від їх хімічного складу i, особливо, вмісту внутрішніх ліпідів. Так, між міцністю волокон та вмістом у них церамідів існує позитивна кореляція. Зокрема, коефіцієнт кореляції між міцністю волокон та вмістом у них церамідів у зимовий період становив - 0,923, весняний 0,989 , літній - 0,827, осінній - 0,786. Позитивна кореляція в усі сезони року спостерігається і між глюкозил церамідами, а найтісніший зв'язок $є$ у весняний період $(\mathrm{r}=0,910)$. Що стосується інших ліпідних компонентів, то їхній зв'язок $з$ міцністю волокон неоднозначний i, очевидно, не може слугувати як інтегральний показник для оцінки якості волокон, зокрема їх міцності.

Таблиця 3

Взаємозв'язки між міцністю вовни і вмістом у ній вільних внутрішніх ліпідів

\begin{tabular}{|c|c|c|c|c|}
\hline \multirow{2}{*}{ Ліпіди } & Зима & Весна & Літо & Осінь \\
\hline & \multicolumn{4}{|c|}{ Вівцематки породи прекос } \\
\hline Загальні ліпіди & 0,250 & $-0,905$ & $-0,932$ & 0,535 \\
\hline Неетерифікований холестерол & $-0,401$ & $-0,919$ & 0,900 & $-0,051$ \\
\hline НЕЖК & $-0,356$ & 0,999 & 0,881 & 0,199 \\
\hline Стеринова фракція & 0,561 & $-0,649$ & $-0,610$ & $-0,735$ \\
\hline Етерифікований холестерол & $-0,500$ & 0,913 & $-0,079$ & 0,654 \\
\hline Гліколіпіди найвищої полярності & $-0,922$ & $-0,170$ & 0,788 & $-0,998$ \\
\hline Холестерол сульфат & 0,451 & 0,293 & $-0,815$ & $-0,913$ \\
\hline Глюкозил цераміди & 0,643 & 0,910 & 0,118 & 0,150 \\
\hline Сульфоліпіди & $-0,733$ & 0,836 & $-0,675$ & $-0,522$ \\
\hline Цераміди & 0,923 & 0,989 & 0,827 & 0,786 \\
\hline
\end{tabular}

Отже, отримані дані чітко вказують на те, що у процесі річного росту вовняні волокна зазнають впливів сезону, які певним чином відображаються на їхній структурі, хімічному складі та фізичних властивостях.

\section{Висновки}

1. Найбільша кількість альфа-кератози міститься у вовні в зимовий-весняний період утримання тварин, 3 настанням літа і до осені кількість цієї фракції зменшується на 2\%. Натомість кількість гамма-кератози у зимово-весняний період низька, а 3 настанням літа зростає на $3 \%$.

2. Найбільш чіткі сезонні зміни серед вільних внутрішніх ліпідів зафіксовані 3 боку холестеролових фракцій. Зокрема, найбільша кількість неетерифікованого холестеролу міститься у вовні зимового росту - 67,2\%. 3 настанням весни кількість цієї фракції зменшується до $62,3 \%$ (Р < 0,01), і ця тенденція продовжується у літній $(61,6 \%, \mathrm{P}<0,001)$ та осінній $(60,8 \%$, $\mathrm{P}<0,01)$ періоди. Щодо етерифікованого холестеролу, то тут спостерігається діаметрально протилежна картина змін.

3. Між міцністю волокон та вмістом у них церамідів існує позитивна кореляція, яка у зимовий період становить $-0,923$, весняний $-0,989$, літній $-0,827$, осінній $-0,786$.
Перспективи подальших досліджень. У подальшому буде продовжено вивчення впливу різних факторів на структуру, хімічний склад та фізичні властивості вовни різних порід овець. Ці дослідження дозволять наблизитися до розкриття механізмів різних вад вовни та запропонувати методи їх запобігання та ліквідації.

\section{References}

Stapay, P.V., Tkachuk, V.M., \& Chokan, T.V. (2014). Hirskokarpatske vivcharstvo [Sheep breeding of Carpathian Mountain]. Lviv, Dobra sprava (in Ukrainian).

Adams, N.R., Masters, D.G., Schlink, A.C., Mata, G., \& O'Dea, T. (1999). Is there a specific weakness in staple strength around the break of season? Australian Journal of Experimental Agriculture. 39(4), 401-409. doi: 10.1071/EA98056

Myros, V.V., \& Fominova, A.S. (2011). Ovcevodstvo i kozevodstvo [Sheep breeding and goat breeding]. Rostov-na-Donu, Fenix (in Russian).

Asquith, R.S., \& Parkinson, D.C. (1966). The morphological origin and reactions some keratin fractions. Textile Research Journal. 36(12), 1064-1071. doi: 10.1177/004051756603601206

Tkachuk, V.M., $\quad$ Havrylyak, V.V., $\quad$ Stapay, P.V., Sedilo, H.M. (2014). Internal lipids of felted, yellowed and pathologically thin wool. Ukrainian biochemical journal. 86(1), 131-138 (in Ukrainian). 
Marti, M., Ramirez, R., Manich, A.M., Coderch, L., \& Parra, J.L. (2007). Thermal analysis of merino wool fibres without internal lipids. Journal Applied Polymer Science. 104, 545-551. doi: 10.1002/app.25586

Marti, M., Ramirez, R., Barba, C. et al. (2010). Influence of internal lipid on dyeing of wool fibers. Textile Research Journal. 80(4), 365-373. doi: $10.1177 / 0040517509339224$
Coderch, L., Méndez, S., Barba C. Pons, R., Martí, M., \& Parra, J.L. (2008). Lamellar rearrangement of internal lipids from human hair. Chemistry and physics of lipids. 155(1), 1-6. doi: 10.1016/j.chemphyslip.2008.05.175

Ramirez, R., Marti, M., Barba, C. Méndez, S., Parra, J.L., \& Coderch, L. (2010). Skin efficacy of liposomes composed of internal wool lipids rich in ceramides. Journal of Cosmetic Science. 61(3), 235-245. doi: 10.1111/j.1468-2494.2010.00619_3.x 